\title{
Determinants of supply chain effectiveness during economic slowdown - an exploratory study of the Indian Textiles Cluster
}

\author{
DOI: $10.35530 / I T .071 .06 .1748$
}

\section{ABSTRACT - REZUMAT}

\section{Determinants of supply chain effectiveness during economic slowdown - an exploratory study of the Indian Textiles Cluster}

This paper aims at studying the functioning of the supply chain in the garment cluster. It identifies key factors that contribute to the effective functioning of supply chain network and practices undertaken to can withstand adverse economic situations. Moreover, it was analysed the payment of dividends to the industry in terms of better business performance. This paper uses a case based exploratory research methodology, which aims to understand the cause and effect relationship between the variables influencing the supply chain network. A comprehensive literature review was undertaken and logical reasoning was applied to propose the hypotheses and the conceptual model. Case studies from various developing nations were considered and a wide variety of supply chain models have been carefully studied to propose the constructs. This has led to the development of a model which is flexible to with stand economic crisis and at the same time effective and more robust enough to support the functioning of the various nodes in the garment supply chain network. This study to the best of author's knowledge have not been undertaken in the garment cluster in a developing nation. The implications of this study is bound to give much needed support and leverage to the frail and underperforming garment cluster which is a major contributor of Gross Domestic Product and employment generator for the growing middle class in these developing nations.

Keywords: supply chain management, supply chain effectiveness, Indian Textile Cluster, economic slowdown, integration, organizational performance, information sharing

Factorii determinanți ai eficienței lanțului de aprovizionare în timpul încetinirii economice - un studiu exploratoriu al Clusterului Textil Indian

Această lucrare are ca scop studierea funcționării lanțului de aprovizionare în clusterul din sectorul de îmbrăcăminte. Sunt identificați factorii cheie care contribuie la funcționarea eficientă a rețelei lanțului de aprovizionare și practicile întreprinse pentru a rezista situațiilor economice dificile. În plus, s-a analizat modalitatea de plată a dividendelor industriei în condițiile de performanță a afacerii. Această lucrare folosește o metodologie de cercetare exploratorie bazată pe studii de caz, care își propune să înțeleagă relația cauză-efect dintre variabilele care influențează rețeaua lanțului de aprovizionare. S-a efectuat un studiu amplu și s-a aplicat un raționament logic, pentru stabilirea ipotezelor și a modelului conceptual. Au fost luate în considerare studii de caz din diferite țări în curs de dezvoltare și o varietate de modele de lanț de aprovizionare au fost studiate cu atenție pentru a propune modelele. Aceasta a condus la dezvoltarea unui model flexibil, pentru a rezista la criza economică și, în același timp, suficient de eficient și robust pentru a sprijini funcționarea diferitelor noduri din rețeaua lanțului de aprovizionare din sectorul de îmbrăcăminte. Acest studiu, după cunoștințele autorului, nu a fost întreprins într-un cluster din sectorul de îmbrăcăminte dintr-o țară în curs de dezvoltare. Concluziile acestui studiu vor oferi suportul necesar clusterului din sectorul îmbrăcăminte, un sector fragil și slab performant, dar contribuitor major al produsului intern brut și generator de locuri de muncă pentru clasa de mijloc în creștere în țări în curs de dezvoltare.

Cuvnte-cheie: managementul lanțului de aprovizionare, eficiența lanțului de aprovizionare, Clusterul Textil Indian, încetinirea creșterii economice, integrare, performanță organizațională, schimb de informații

\section{INTRODUCTION}

\section{Growth of Indian economy}

India since independence understood the primitive role of the manufacturing sector in realizing the dreams of setting up the "socialistic pattern of the society". Thus after gaining independence in 1947, a number of industrial policies were taken up to foster the growth of manufacturing sector in India. Out of those, two important policies which were taken up immediately after the independence were Industrial Policy Resolution of 1948 and Industrial Policy
Resolution of 1956. These two policy resolutions helped the development of the industries to a great extent, but on account of the excessive regulatory interference, red tapes, protocols, cap on foreign investment, adverse tax law provisions and excessive government control the anticipated growth rate could not be achieved. In the initial years of planning, the thrust was to develop the manufacturing base by setting up heavy industry, towards which the organized manufacturing sector was mainly producing basic intermediate goods and machinery. The 1980s saw a clear departure from this strategy with partial 
liberalisation, as consumer goods became the dominant industry. The introduction of economic reforms in the 1990s led to growth of the consumer durables industry and export-dependent growth. Both these strategies made growth more volatile since demand for consumer durables is income-elastic and export growth is based on international demand [1]. During the month of January 2019, 11 out of the 23 industry groups (as per 2-digit NIC-2008) in the manufacturing sector had shown growth, as compared to January 2018.

\section{Contribution of textile industry to the growth of the Indian economy}

India is one of the world's huge manufacturers of garments and textiles oriented products. Today the Indian textile industry is one of the most important and vital industry of the economy not only in terms of output but also in terms of foreign exchange earnings and employment generation [2].

Indian textile industry has suffered in the past from low productivity at both ends of the supply chain low farm yields affecting cotton production and inefficiency in garment sector due to restriction of size and reservation [3]. Cotton is an important fiber and cash crop, which plays a dominant role in the industrial and agricultural economy of India. India is placed at the number two position for production of cotton in the world market and is among the preferred sourcing sites for various international textile brands and retailers. As per the latest international reports, for the year 2018-2019, India is about to lose its "top cotton producer" tag to China, which has shown improved yields with better farming practices [4].

\section{Economic slowdown}

India had faced a few recession phases in the past 10 years. During the period of 1958-1959 recession, India went through a foreign exchange crisis. In the year 1966 recession the railways and defence were major customers and the monsoon failures of the year 1966 and 1967 had reduced their budget allocations. The recession of 1973 was triggered by the oil crisis. India was still a substantially closed economy and so was less affected by the global recession, under which the US, Europe and Japan were reeling. However, India could not escape the costs of high dependence on imported crude oil. The recession of 1981 led more Indian companies to take interest in Japanese management techniques like Kaizen, Kanban, Just in Time (JIT). During the recession of 1996 the RBI over-reached itself in controlling inflation, touching $2 \%$, though $4 \%$ was a more sustainable rate for a high growth economy. Except petroleum and rubber goods, most of the other industries like mining and quarrying, heavy inorganic chemicals, cement, basic metals, iron and steel, aluminium, electrical goods show a decline in growth rate until 1966 .

The development of the Indian economy during 80's and 90's depended heavily on the import of oil; this development curve took a serious hit during 1973

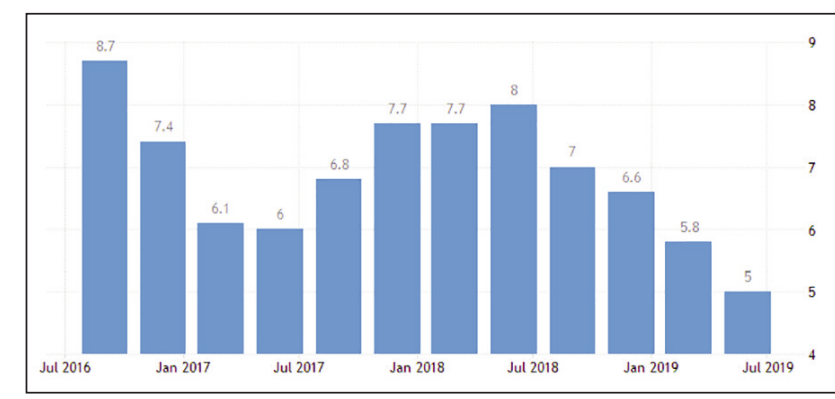

Fig. 1. GDP growth rate (2016-2019) [5]

because of the oil crisis which was brought about by the Iran-Iraq war. The global recession during the 1980's stifled the Indian exports which led to India facing a Balance of Payment (BoP) crisis. India found itself facing macro-economic crisis during 1990's with acceleration of inflation, unsustainable fiscal deficit and a very fragile Balance of Payment situation.

Therefore, it's evident that India has faced recession the years: 1958 - foreign exchange crisis, 1966 railways and defence were major customers and the monsoon failures of the year had reduced their budget allocations; 1973 - oil crisis; 1980 - India's exports suffered during this time; 1991 - 'balance of payment' crisis; 1997 - Asian crisis (currency crisis/financial crisis) [6], 2000-2001 - dot com crash [7]; 2008 - IT, automobiles, industry and export-oriented firms.

Presently the Indian economy is experiencing slow down. The GDP growth rate had slowed down considerably to a meagre 5\% during April - June quarter of 2019-2020 which had a domino effect on the job market, where the unemployment rate dropped to $3.4 \%[7]$.

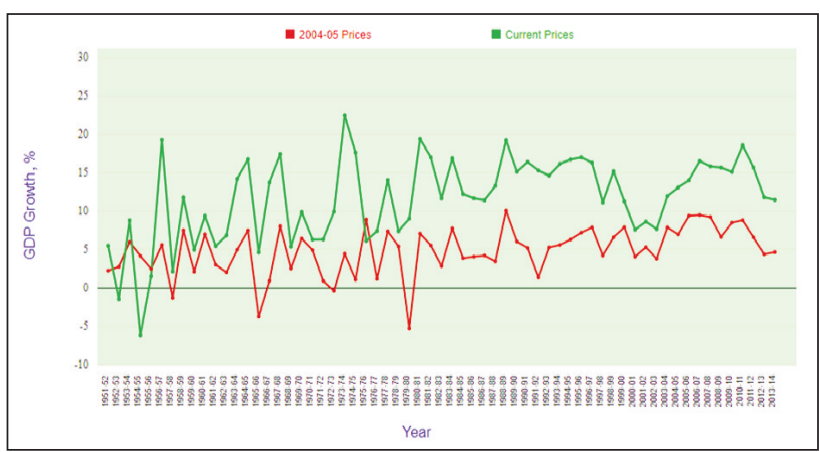

Fig. 2. GDP growth of India (1951 - 2014) [9]

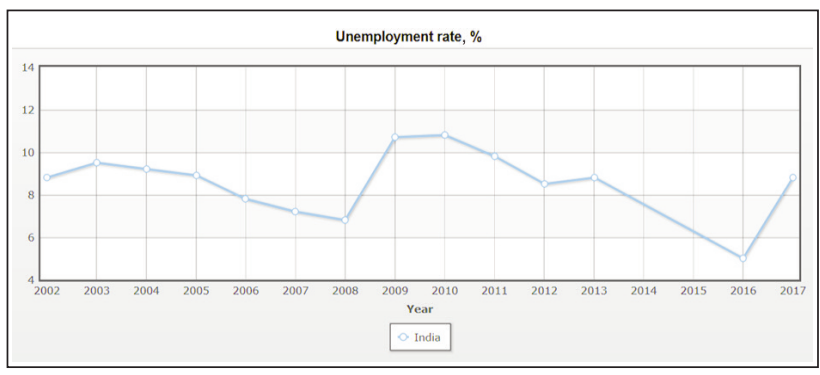

Fig. 3. Unemployment rate (\%) [10] 


\begin{tabular}{|l|c|c|c|c|c|c|}
\hline \multicolumn{2}{|c|}{ RECESSION DRIVING VARIABLES AND GDP GROWTH RATE DURING CORRESPONDING YEARS [8] } \\
\hline \multicolumn{1}{|c|}{ Driving variable } & Recession & From & To & $\begin{array}{c}\text { GDP before } \\
\text { recession } \\
\text { (\%) }\end{array}$ & $\begin{array}{c}\text { GDP during } \\
\text { recession } \\
\text { (\%) }\end{array}$ & $\begin{array}{c}\text { GDP after } \\
\text { recession } \\
\text { (\%) }\end{array}$ \\
\hline Foreign Exchange Crisis & 1 & 1958 & 1959 & 3.6 & 76.78 USD & 3.7 \\
\hline Railways and Defence & 2 & 1965 & 1966 & 7.5 & -0.1 & 7.8 \\
\hline Oil Crisis & 3 & 1972 & 1973 & 1.6 & -0.6 & 1.2 \\
\hline Exports & 4 & 1979 & 1983 & 5.7 & -5.2 & 3.8 \\
\hline "Balance of Payment" Crisis & 5 & 1990 & 1991 & 5.9 & 1.1 & 5.5 \\
\hline $\begin{array}{l}\text { Asian Crisis (Currency Crisis/Financial } \\
\text { Crisis) }\end{array}$ & 6 & 1996 & 1997 & 7.5 & 4.0 & 6.1 \\
\hline $\begin{array}{l}\text { Dot com Crash } \\
\text { IT, Automobiles, Banking and Financial } \\
\text { sector, Industry and Export-oriented Firms }\end{array}$ & 7 & 2007 & 2009 & 9.3 & 3.9 & 10.3 \\
\hline
\end{tabular}

\begin{tabular}{|c|c|c|c|c|c|c|c|c|c|c|c|c|c|c|}
\hline \multicolumn{15}{|c|}{ UNEMPLOYMENT RATE [10] } \\
\hline Country & 2002 & 2003 & 2004 & 2005 & 2006 & 2007 & 2008 & 2009 & 2010 & 2011 & 2012 & 2013 & 2016 & 2017 \\
\hline India & 8.8 & 9.5 & 9.2 & 8.9 & 7.8 & 7.2 & 6.8 & 10.7 & 10.8 & 9.8 & 8.5 & 8.8 & 5 & 8.8 \\
\hline
\end{tabular}

\section{Textiles industry today in slowdown situation}

The Director General of Commercial Intelligence of Statistics recorded an average fall of $34.6 \%$ in the cotton yarn exports from India during April 2019. The economic slowdown saw textiles spinning mills which were once running round the clock, limit their operations and functioned only to their half capacity.

India has around 4,500 ginning units, of which 2,100 are non-operational. Gujarat has 1,300 ginning units, comprising 700 operational and 600 non-operational units. Maharashtra has 1,200 units (700 operational and 500 non-operational), South India has 1,000 units (500 operational and 500 non-operational), North India has 600 units (300 operational and 300 non-operational) (Ginning mills status in 2015). Knitting factory in India is providing huge collection of Knitted fabric, which are accessible in different styles and textures. There are lots of dependable manufacturer, exporter as well as supplier of knitted fabrics in India. The Northern India Textile Mills Association (NITMA) has claimed that the cotton and blends spinning industry is witnessing the biggest crisis in the past nine years. Their estimates reveal that 50 lakh job cuts owing to the economic slowdown in India.

\section{Significance of effective supply chain in garment industry}

Supply chain management is becoming a crucial part of textiles and apparel business. In addition to the traditional concepts on improving the production efficiency, quality control, and product design, supply chain management focuses on enhancing the collaboration and cooperation among all companies in the supply chain with a goal of satisfying market requirements [11]. In the era of global supply chains, the management of sourcing, production, and distribution in partnerships with suppliers and distributors, has become a top priority for manufacturing firms to gain competitive advantages in the marketplace [12]. It has been observed that firms do not compete individually but their supply chains do [13, 14]. Necessity to have an effective supply chain has become vital for survival essentially at the time of economic slowdown. Effective SCM implementation requires shared goals setting, collaborative planning, shared risk and reward sharing, and information sharing [15-20]. Therefore, this paper focuses on understanding the necessity of having an effective supply chain to withstand situations like economic slowdown/recession.

\section{STATEMENT OF THE PROBLEM}

Businesses in the under developed and developing countries are not able to withstand competition. This is because of rising cost of raw materials, as there are no raw material suppliers within the country who are able to meet the demand of the businesses at the rate they quote. Therefore, customer expectations are not being met within the time promised. India being a cash based economy faces financial pressure within the members of supply chain because of the changes brought in the government policies to adopt digital currency and electronic payment methods. This has led to cash crisis and strangling the supply chain network. Since, there are no steady supply of raw materials within the nation, the business units are forced to depend on other nations for raw material supply. High import duties and trade restrictions hamper easy flow of material, information and money through the supply chain network. High employment generating garment sector today is fac- 
ing the problem of non-availability of skilled work force forcing manufacturing units to consider shifting operations to other developing nations like Vietnam and Bangladesh.

\section{REVIEW OF LITERATURE}

Talavera had pointed out that an effective Supply Chain Management implementation involves shared goals setting [21], collaborative planning, shared risk and reward sharing, information sharing, and supply chain integration [15-20].

Collin and Lorenzin [16], had indicated that an effective supply chain must be responsive to customer requirements and flexible to demand-and-supply challenges.

The supply chain efficiency can be evaluated by improving firm's capability to reduce its supply chain costs [20, 22-24].

Hwang and Lu [20] had proposed that quicker timeto-market, minimal costs, maximum responsiveness and superior service quality, are crucial to integrate the value chain.

Ponomarov and Holcomb [25] had pinpointed that the supply chains should have preparedness plan at the time of the economic slowdown to reduce the likelihood of disruptive events.

Bigelow and Chan [26] had indicated that an important step to be remembered during an economic slowdown is to have strong handling efforts.

An organization's initial conditions in terms of its current stocks of resources and capabilities [27], during the economic slowdown/recession, will mitigate or accentuate recessionary pressures and subsequently influence firms' short-term response and performance

Dierickx and Cool [27] had drawn attention to the point that an organization's initial conditions in terms of its current stocks of resources and capabilities during the economic slowdown/recession, will accentuate recessionary pressures and influence firms' short-term response and performance. Hence, bringing in changes in organizational performance during recession helps in withstanding the tide.

Tan and Kannan [28] had pointed out the importance of adapting business models in the strategy of firms is imperative as well as the need. Bringing in changes in business procedures with trading partners during economic slowdowns will help in reducing the credit-risk levels.

\section{RESEARCH METHODOLOGY}

This study adopts an exploratory case based approach. A detailed literature study was conducted and fact statements from peer reviewed journals of the highest category were drawn on various scenarios on the subject of study. These fact statements were carefully compared and contracted to identify the research gaps. Historical data from various companies were carefully studied and common threats to surviving companies were identified and measures taken by these companies to withstand changes in the market and defend against threats were analyzed. A sequence of historical events and economic slowdown scenarios from various developing nations were studied. Careful observation of literature has led the researchers to propose robust hypotheses. Statistical proof of economic slowdowns were drawn from authenticated and credible secondary sources such as the World Bank report [8], Planning Commission - Government of India [9], CIA World Factbook [10], etc. Drivers of an effective supply chain under conditions of economic slowdown are laid down after an in-depth study of literature. This paper seeks to propose and validate suitable model for an effective supply chain under a situation of economic recession.

\section{NOTABLE COMPANIES OF THE WORLD THAT PERFORMED DURING ECONOMIC CRUNCH}

United Technologies Corporation (UTX) and The Boeing Company (BA) were top performers during 1973 recession. Toyota was one such automobile manufacturing firm, which was able to withstand the tide. After the 1973 oil crisis, oil and gas companies owned by Saudi Arabia, Russia, China, Venezuela, Brazil and Malaysia which created world class brands like Aramco, Gazprom, Petrobras, etc. established their dominance in this industry [29, 30].

Wal-Mart (WMT), American Express (AXP) and McDonald's (MCD), were the companies which all jumped over $100 \%$ during 1980 recession.

Bungie (game developer for the Mac platform) is a successful tech companies to emerge out of the recession of 1990 and 1991. UnitedHealth Group (UNH), Cisco (CSCO), and Home Depot (HD) were all top performers during 1990 recession.

The companies Infosys, Wipro, Satyam [7], HP, IBM, Dell, Amazon.com, eBay, Priceline.com, Shutterfly (internet-based personal publishing), Coupons.com, Microsoft were able to picking up new clients and were hoping to increase business even during 2000 - 2001 recession.

The companies which thrived during the great recession between the year 2007-2009 were Amazon (online shopping), Ford (automobile), Domino's (fast food), Snuggie (blankets), Intel (IT), Lego (toy manufacturing), Groupon (which sends out daily email discounts), Wells Fargo (selling of financial products), ETrade (online brokerage firm), Netflix (ideo-ondemand services), Citigroup (investment bank and financial services), Walmart. They grew a profit, despite the bad economic climate. The multinational investment bank and financial services company, which withstood the tide of 2008 financial crisis, was Goldman Sachs.

\section{LESSONS FROM DEVELOPING NATIONS ON HANDLING EFFECTIVE SUPPLY CHAIN DURING ECONOMIC CRISIS}

Case 1: Japan

The success of the Japanese automotive and electronic sector depended heavily on the strength of the 
relationship between the supply chain partners. The mounting pressure by the industrial customers led them to search for technical and managerial solutions that would be commercially viable and flexible enough to face growing world competition [31].

Japan had faced recession during Quarter 2 in 2008 until Quarter 1 in 2009 (12 months), Quarter 4 in 2010 until Quarter 2 in 2011 (9 months) and Quarter 2 in 2012 until Quarter 3 in 2012 (6 months), considering the period between 2006 and 2013.

During recession, the long-term relationships between Japanese firms and their first-tier suppliers were balanced by managing the core things. The primary pressure were laid on the suppliers for reducing costs with their own initiatives; the supply of materials were 'rationalized'; customer's cross functional teams rarely involved suppliers; buyers preferred to re-source; suppliers were encouraged to deal with the parent company's competitors as well; the first tier suppliers were expected to manage the second tier relationships. Set of companies with interlocking business relationships appeared to be weakening. Relationship with the overseas suppliers was managed by bringing in changes in their sourcing strategies. No sign of Japanese firms repatriating business from overseas; businesses were switched from the West to East Asia; East Asian firms developing capabilities: import reliance on Japan may lessen, new offshore sourcing by Japanese companies is likely but only in East Asia; re-sourcing preferred where 20\% saving is possible (25\% for new non-Japanese source) [31].

\section{Case 2: Vietnam}

The 20 year old Vietnam War which ended during 1975 brought the economy to its knees by mid1980's, the per capita GDP plunged to less than $\$ 300$. During 1986 the government of Vietnam introduced a series of economic and political reforms called "Doi Moi" to steer the country towards a socialist market economy. These reforms were instrumental in pulling up the economy even after the wake of global recession which hit during the 2000's [32].

Vietnam faced several weaknesses and macroeconomic risks in their economy, which were hidden until 2007 by a relatively high economic growth [33]. They predicted that the global crisis will affect Vietnam's macro economy in five ways. Demand for some Vietnamese exports will weaken, foreign investment will fall over the short to medium term, tourist arrivals are also likely to fall, remittances from overseas could fall and finally the fall in commodity prices will result in a shortfall in government revenues [34].

The sustained growth of the Vietnamese economy was largely due to trade liberalization, domestic reforms through deregulation and providing investment support for new businesses [32].

\section{Case 3: Cambodia}

Cambodia's clothing industry grew adversely during the decade 1995-2005. From a very low base in the early 1990s the growth rate averaged $60 \%$ per annum between 1995 and 2000, dipping a little during the years of political crisis in 1997-1998. From 2001 to 2005 it grew at a steadier rate of $20 \%$ per annum. As a result, its share of GDP rose from less than $1 \%$ in 1993 to over $15 \%$ in 2005 , while its share of manufacturing industry rose from $9 \%$ to $77 \%$. No other sector has been able to increase its share of the economy in this manner [35]. The recent development of the Cambodian economy has been heavily dependent on the increase of garment export industry [36].

The garment industry in Cambodia in the past depended largely on the import of yarn, finished woven's and knitted fabrics, but the principle of cutmake-trim model coupled with assembly of products has proved to be profitable for Cambodia's garment industry [37].

\section{SUPPLY CHAIN MODELS}

Kai Hoberg and Knut Alicke [38] had proposed five action areas that must be considered in parallel, which will cause exceptional challenges for supply chain managers while also dealing with all types of operational glitches. They believed that firms should begin to prepare as early as possible for difficult times ahead. So that they will not only benefit in the crisis but actions are also beneficial to the business from a long-term perspective.

Tom Holland and Jeff Katzin [39] model demonstrates that all companies fall into anyone of the four basic quadrants which will determine cost program, supplier strategies and financial positions needed for sustainable growth.

Christopler et al. [40] in their model, they had structured the horizontal axis in such a way that it shows the demand characteristics in terms of "predictability". This is likely to be determined by the variability of demand, hence measures such as the Coefficient of Variation could be used to position products on that axis. The vertical axis reflects the replenishment lead

\begin{tabular}{|c|c|c|}
\hline & Action Area & Key Actions \\
\hline (1) & $\begin{array}{l}\text { Understanding } \\
\text { True Demand }\end{array}$ & $\begin{array}{l}\text { - Identify reliable information } \\
\text { - Communicate with customers } \\
\text { - Develop demand scenarios }\end{array}$ \\
\hline (2) & $\begin{array}{l}\text { Monitoring and } \\
\text { Safeguarding Supply }\end{array}$ & $\begin{array}{l}\text { - Identify supplier criticality } \\
\text { - Monitor supplier health and lead times } \\
\text { - Ensure the survival of critical suppliers }\end{array}$ \\
\hline (3) & $\begin{array}{l}\text { Creating Flexible, } \\
\text { Breathing Supply Chains }\end{array}$ & $\begin{array}{l}\text { - Understand the effects of demand fluctuations } \\
\text { - Convert fixed costs into variable costs } \\
\text { - Define smart contracts }\end{array}$ \\
\hline (4) & $\begin{array}{l}\text { Aligning Inventories to } \\
\text { Free Up Cash }\end{array}$ & $\begin{array}{l}\text { - Avoid surplus-inventory intake } \\
\text { - Align inventory policies } \\
\text { - Streamline service offerings }\end{array}$ \\
\hline (5) & $\begin{array}{l}\text { Preparing for } \\
\text { Upswing }\end{array}$ & $\begin{array}{l}\text { - Retain and develop talent } \\
\text { - Prepare long-term projects } \\
\text { - Provide upside capacity }\end{array}$ \\
\hline
\end{tabular}

Fig. 4. Action areas for Supply Chain Management during periods of economic crisis [38] 


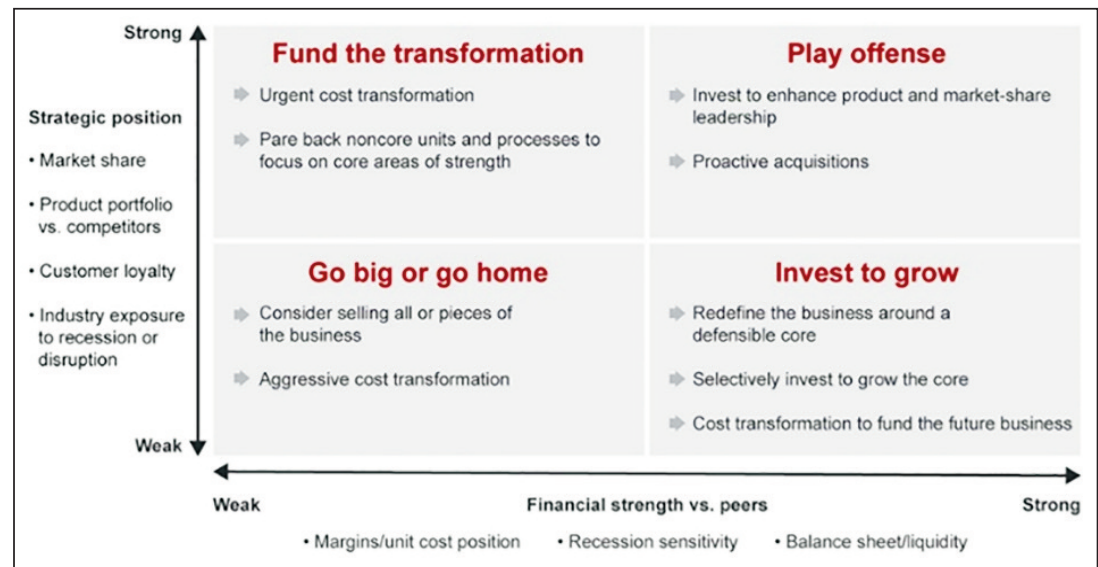

Fig. 5. Taking advantage of a downturn starts with a realistic assessment of a company's strategic and financial starting positions [39]
Scott Latham [41] model comprises five distinct constructs form the literature which additionally includes seven distinct linkages within the model representing the dynamics between constructs - and the bases for their propositions. The first contention is, that an organization's initial conditions in terms of its current stocks of resources and capabilities at the onset of the economic recession, will mitigate or accentuate recessionary pressures and subsequently influence firms' short-term response and performance (i.e. intra-recessionary) performance (Proposition 1). times for the same product. Effectively this is measuring the time it would take the system to respond to an increase in demand if materials etc. had to be sourced or manufactured. If this elapsed time is measured in months rather than days then that product could be regarded as having a long re-supply lead time.

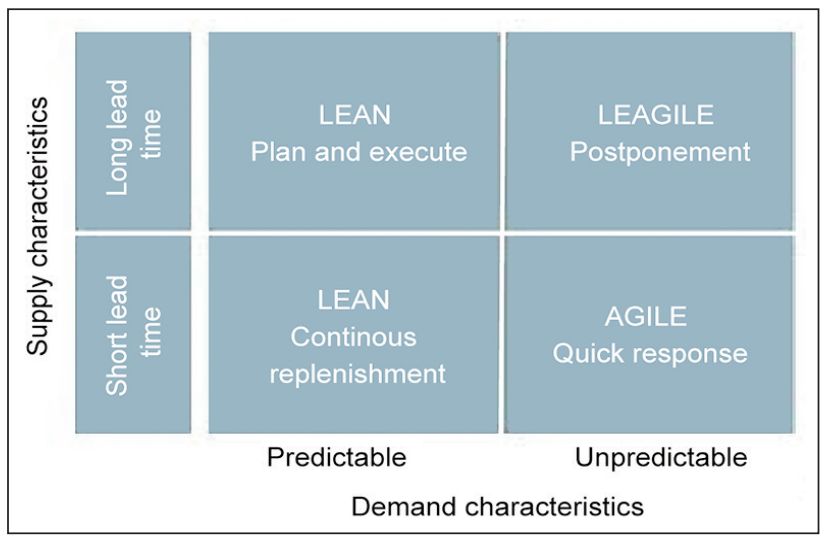

Fig. 6. Demand and supply characteristics and pipeline selection strategy [40]

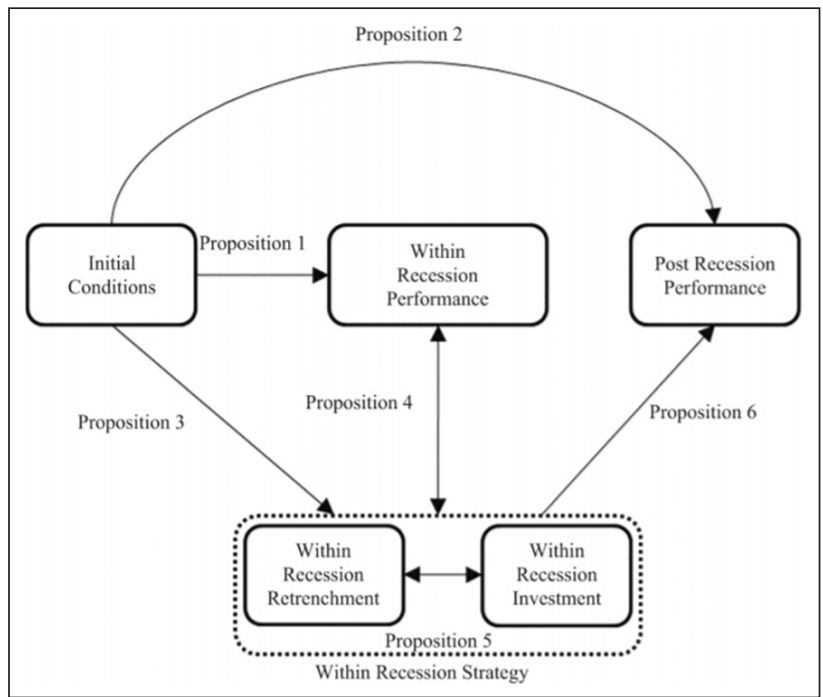

Fig. 7. An integrated framework for understanding firm level dynamics during recession [41]
Furthermore, they expect initial conditions to partially determine the firm's long-term performance, including survivability and competitive advantage, once the recession ends (Proposition 2). Given the detrimental nature of recessions on firms' short and long-term viability, and in keeping with the majority of extant literature on firm strategies during economic downturns they attend to the performance construct in terms of accounting-based performance metrics (e.g. sales, ROA, ROS, etc.). Their third proposition holds that organizations' initial conditions, which more often than not are a by-product of past decisions, will dictate firms' strategic decision-making in response to recessions (Proposition 3 ). The next phase of the model deals with the unique interplay between within-recession performance and within-recession strategy (Proposition 4 and 5). The interactions as discussed has significant repercussions for firms' post-recessionary performance (Proposition 6). Their final proposition demonstrates the effect of the recurring nature of recessions on firms' competitiveness and subsequent performance over multiple business cycles (i.e. economic growth and retraction) (Proposition 7).

\section{CONSTRUCTS IDENTIFICATION}

Careful study of the literature and various supply chain models had paved way to identify the following constructs.

- Shared goal setting

- Collaborative planning

- Risk and Reward sharing

- Information sharing

- Supply Chain Integration

- Flexibility to demand and supply challenges

- Supply Chain cost

- Responsiveness to the economic environment

- Recession preparedness plan

- Recession handling effort

- Change in organizational performance during recession

- Change in business procedures with trading partners 
HYPOTHESES DEVELOPMENT FOR EFFECTIVE SUPPLY CHAIN DURING ECONOMIC CRISIS

\section{Shared goal setting}

From a study conducted by John W. Haas, Beverly D.S. and Sypher H.E. [42], it was evident that perception of shared goals among organizational members are positively related to important organizational outcomes, such as commitment, job satisfaction and communication satisfaction.

H1: Goal setting process in surviving supply chain is clearer and more accurate than other supply chains.

\section{Collaborative planning}

Forecasting is challenging and there are only a handful of customers who are really committed to accurate forecasts. That's the reason behind, why true process collaboration with all stakeholders is so crucially important. The consolidated demand plan is shared in a continuous manner with all the organizations contributing to its fulfilment. Continuous planning is practically the only way to make supply chain for effective and efficient. Therefore, the key point is that collaborative planning should be seen as a process of continuous development that will systematically improve itself in the course of time [16].

H2: Collaboration is more efficient and robust in surviving supply chain than other supply chains.

\section{Risk and Reward sharing}

Cooper [16, 43] highlighted that efficient management of supply chain depends upon sharing risk and reward among the supply chain network partners. The risk and reward sharing capability of firms in supply chain network will evenly spread and level out the potential risks and returns between strategic partners $[43,45]$.

H3: Reward and risk sharing is more transparent in surviving supply chain than other supply chains.

\section{Information sharing}

Modularization and reconfiguration of business processes as well as ease of information sharing with customers, suppliers and other business partners $[46,47]$ becomes primarily important to maintain an effective supply chain.

H4: Information sharing is much more dynamic in surviving supply chains than other supply chains.

\section{Supply Chain Integration}

New argued that integration can be understood in three ways: operational integration (coordinating inventory, scheduling, transport, new product development), functional integration (managing different managerial functions such as purchasing and inventory management), and relational integration (improving boundary relations). Supply chain integration increases performance if supply complexity is high, while a very limited or no influence of supply chain integration can be detected in case of low supply complexity [48].

H5: Supply chain integration ensures performance in an effective supply chain than other supply chains.

\section{Flexibility to demand and supply challenges}

Mature supply chain firms have developed the ability to adapt to uncertainty in the environment through creating flexible policies and procedures and by minimizing the rules for significant performance in the market $[49,50]$.

H6: Surviving supply chains react better to change in market conditions than other supply chains.

\section{Supply Chain cost}

Supply chain costs are complex because there are so many variables. Thus, the costs should be considered as aggregate and not as individual costs. There seems to exist considerable advantage when it comes to variable cost supply chain operations than performing with the traditional cost model. This variable cost structure has a favorable impact on the growth prospects of the firms compared to that of the traditional fixed cost structure. One of the most appropriate time to consider a variable cost structure in the supply chain functioning is during the time of recession and economic slowdown. This variable cost approach has proved to be a risk minimizing factor for enterprises performing under economic slowdown [51].

H7: Effective supply chains are able to scale up operations during varied cost structures than other supply chains.

Responsiveness to the economic environment

To achieve shorter time-to-market, lower costs, higher responsiveness and better service quality, it is critical to integrate the value chain of semiconductor industry [20].

H8: Surviving supply chains respond better to adverse economic environment compared to other supply chains.

\section{Recession preparedness plan}

From Ponomarov and Holcomb [25] research it's evident that supply chains should have required level of readiness/preparedness at the time of the economic slowdown to reduce the likelihood of disruptive events or recession. They have also pointed out that failure to develop required readiness, response and recovery abilities makes the supply chain vulnerable, which adversely affects both revenue and cost of the whole chain. It is worth noting that supply chain readiness, response and recovery are interdependent to each other as preparedness of supply chains accelerates a quicker response and recovery from the crisis $[52,53]$. Any event, which disturbs a supply chain, can lead into a supply chain crisis due to the propagation of disturbance along the supply chain network [54]. Richey [55] mentions "preparedness" and "recovery", and Natarajarathinam et al. [56] state the need for avoiding crisis and overcoming it.

H9: Surviving supply chains have a clearer recession preparedness plan than other supply chains.

\section{Recession handling effort}

Traditional methods of dealing with a recession (e.g. layoffs and reduced expenditures in maintenance, research and development (RandD), advertising, process improvements and product improvements) are no longer viable options for all companies. The first key to successful downsizing lies in the handling of the people. The important step in handling an effective downsizing operation at the time of recession is 
to reduce the workload [26]. The saying "the best defence is a well thought-out offence" applies to management in at terrible times such as recession. The appropriate way for a firm to handle such times is to plan for them ahead of time. A management team that is adroit at planning and implementing recession strategies can sometimes use the circumstances of a recession to expand market share. Recessions are part of the normal cycle of business - it is certain that they will sooner or later occur. Therefore, it makes just as much sense to plan for recessions or downturns as it does to plan for good, economic times [26]. H10: Surviving supply chains have appropriate recession handling efforts compared to other supply chains.

\section{Change in organizational performance during} recession

Recession emerge in an unexpected fashion with no present time frame. Therefore it's vital for any organisation to be prepared for bringing in changes in their performance for bearing the crisis situation. An organization's initial conditions in terms of its current stocks of resources and capabilities [27], during the economic slowdown/recession, will mitigate or accentuate recessionary pressures and subsequently influence firms' short-term response and performance [41].

H11: Surviving supply chains have an adaptive organizational performance than other supply chains.

Change in business procedures with trading partners
Changes are inevitable for businesses whose leaders seek to achieve the mission, vision, and objectives of the organization [57]. Supply chain partners also make strategic choices in terms of supplier partnering, cross-functional teams, and closer customer relationships in order to achieve integration [58]. The importance of adapting business models in the strategy of firms is imperative as well as the need for new designs of inter-firm networks. Because of the fact that supply chain management has a significant impact on overall business performance [28].

H12: Transaction procedures are more adaptable in a surviving supply chain than other supply chains.

\section{DISCUSSIONS}

Proposed conceptual model for supply chain effectiveness during economic slowdown

Before outlining the implications of the study's findings certain limitations needs attention. Out of the three cases cited here, the timing of the recession in two cases namely Vietnam and Cambodia happened fairly long time ago. Japan's case scenario was recent enough to give insights in to the current economic crisis facing the industries in the developing nations. The actual data availability on the performance of the supply chains in the garment cluster in these nations was difficult to obtain. While coming to the implications and observations of the study, the paper high lights the significance of how economic recessions represent an enduring environmental force which results in large-scale changes across

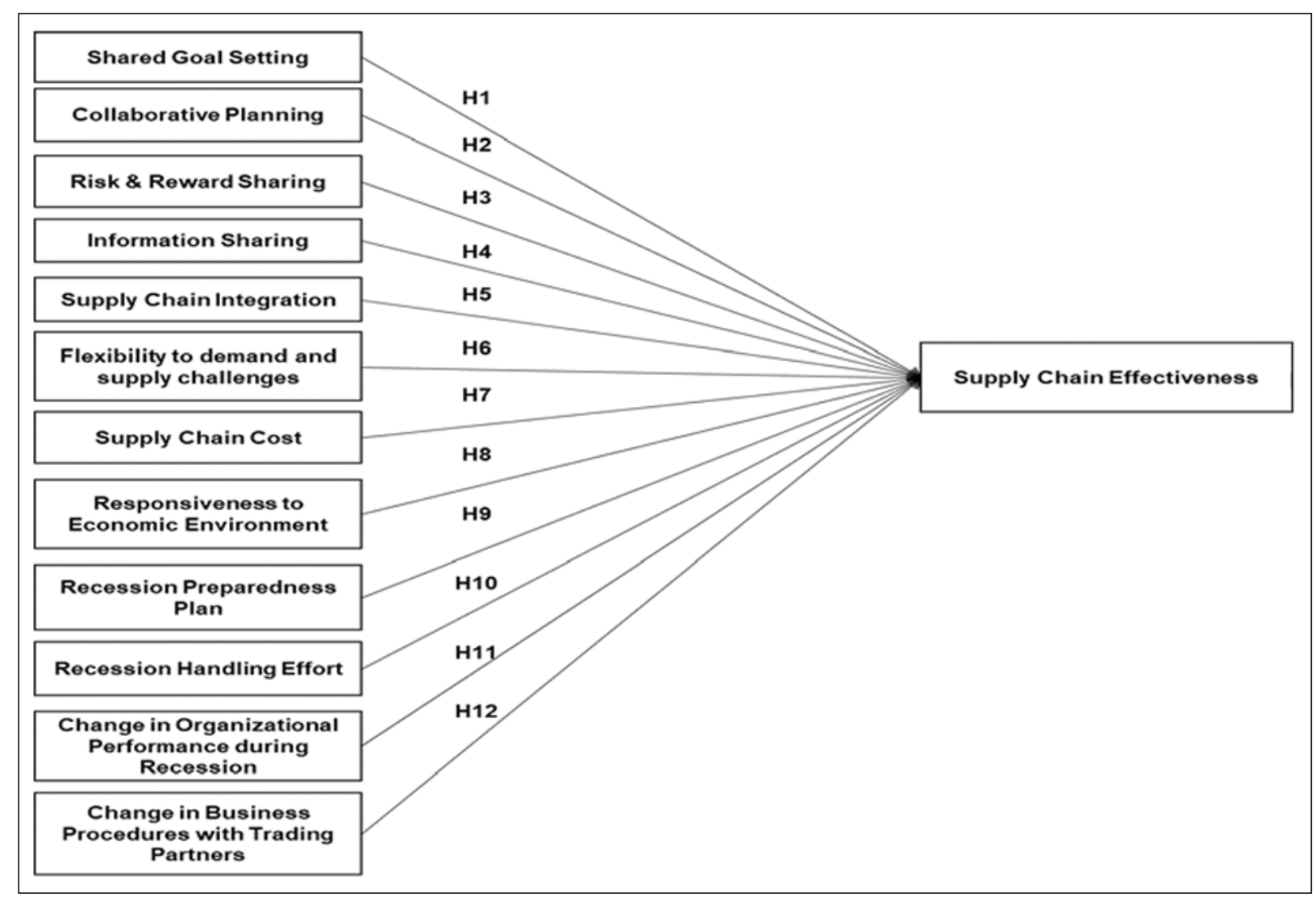

Fig. 8. Proposed Model 
markets, industries, and firms. It is observed that certain notable companies of the world have sailed through the current of recession smoothly to emerge with a more mature and robust supply chain than others who have vanished from the market. These companies today make it into the top fortune 500 company list due to their seem less performance and their ability to manoeuvre through economic crisis and prove to be role models for other underperforming firms. The supply chain model 1 which has been included in the paper as figure 4 discusses the five main action areas such as understanding demand, safe guarding supply, creating flexible supply chain, aligning inventories and preparation for up scaling the entire network as the focus areas to ensure free flow of material, money and information. The model shown in figure 5 discusses the strategies and position that the network partners of the supply chain take in terms of strategic positions taken by the firms during recession to avoid financial crisis. The model proposed by Christopher et al. [40] (figure 6) discusses shortening the time lag to respond to variable demand and sourcing of materials. This model looks at the supply chain from a lean perspective thereby capturing and processing demand within the stipulated time. Latham and Braun [41] model shown in figure 7 proposes five distinct constructs such as holding adequate stock of resources to relieve recessionary pressure. The model highlights the importance of a healthy initial condition which arises out of strategic decision making and unique inter play between the supply chain members to withstand competition and perform better over the economic cycle. Based on the careful study of various supply chain models, the study proposes twelve independent constructs which can be seen in figure 8 as independent drivers for an effective supply chain to function in an adverse economic scenario. The textile cluster depends on each one of these drivers to overcome economic and environmental challenges that is bound to arise during the various phases of a business cycle.

\section{CONCLUSION}

In conclusion, this study sought to improve the understanding on the key drivers that propel firms in the textile cluster through cyclic and erratic economic conditions. By observing cases from developing nations and by meticulous analysis of various supply chain models under recessionary conditions, the study has arrived at a robust model that would prove to be efficient in managing the supply chain network.

\section{REFERENCES}

[1] Unni, J., Economic Reforms and Labour Markets in India: Organised and Unorganised Sectors, In: Shuji Uchikawa (ed), Labour Market and Institutions in India: 1990s and Beyond, Manohar, New Delhi, 2003

[2] Sharma, M., Prashaant, A., An analysis of performance of the Indian textile industry in quota free regime, In: Paradigm, 2009, 13, 2, 98-109, Available at: https://search.proquest.com/docview/214409719?accountid= 38609 [Accessed October 2019]

[3] Chandra, P., The textile and apparel industry in India, IIM-A, Ahmedabad, India, 2006

[4] Rutam, V., The Hindu Business line, 2019, Available at: https://www.thehindubusinessline.com/economy/agribusiness/india-set-to-lose-no-1-cotton-grower-tag-to-china/article26186624.ece [Accessed February 2019]

[5] India GDP Annual Growth Rate1951-2020 Data, Available at: https://tradingeconomics.com/india/gdp-growthannual [Accessed October 2019]

[6] Gupta, D., Has India escaped the Asian economic contagion?, In: South Asia: Journal of South Asian Studies, 2000, 23, s1, 179-192

[7] British Broadcasting Corporation (BBC), India loses place as world's fastest-growing economy, India Today, New Delhi, 2001-2019, Available at: https://www.macrotrends.net/countries/IND/india/gdp-growth-rate, https://www.indiatoday.in/magazine/economy/story/20010514-indian-software-industry-feels-it-stands-to-gainfrom-global-economic-slowdown-776267-2001-05-14 [Accessed September 7, 2019]

[8] Central Statistical Organisation, Estimates by World Bank 2019, International Monetary Fund - World Economic Outlook, Available at: https://www.imf.org/en/Publications/WEO/Issues/2019/01/11/weo-update-january-2019 [Accessed October 2019]

[9] Planning Commission, Government of India, Available at: https://niti.gov.in/planningcommission.gov.in/docs/ data/datatable/index.php?data=datatab [Accessed October 2019]

[10] CIA World Factbook, Available at: https://www.indexmundi.com/g/g.aspx?v=74\&c=in\&l=en, CIA World Factbook https://www.intrafocus.com/kpi-library/supply-chain-effectiveness/ [Accessed October 2019]

[11] Prabavathi, V., Vanathi, R., Role of supply chain management in indian textile industry and the key issues faced by the textile supply chain, In: Journal of Contemporary Research in Management, 2019, 14, 2, 19-28

[12] Mabert, V.A., Venkataramanan, M.A., Special research focus on supply chain linkages: challenges for design and management in the 21st century, In: Decision Sciences, 1998, 29, 3, 537-552

[13] Christopher, M., The supply chain of the future, 2011, Available at: www.martin-christopher.info/news/supply-chainof-the-future/ [Accessed October 16, 2011]

[14] Lambert, D.M., Cooper, M.C., Issues in supply chain management, In: Industrial Marketing Management, 2000, 29, 1, 65-83

[15] McLaren, T.S., Head, M.M., Yuan, Y., Supply chain management information systems capabilities: An exploratory study of electronic manufacturers, In: Information Systems and e-Business Management, 2004, 2, $207-222$ 
[16] Collin, J., Lorenzin, D., Plan for supply chain agility at Nokia: Lessons from the mobile infrastructure industry, In: International Journal of Physical Distribution and Logistics Management, 2006, 36, 6, 418-430

[17] Fredriksson, P., Mechanisms and rationales for the coordination of a modular assembly system: The case of Volvo cars, In: International Journal of Operations and Production Management, 2006, 2, 6, 3-4, 350-370

[18] Varma, S., Wadhwa, S., Deshmukh, S.G., Evaluating petroleum supply chain performance: Application of analytical hierarchy process to balanced scorecard, In: Asia Pacific Journal of Marketing and Logistics, 2008, 20, 3, 343-356

[19] Sundram, V.P.K., Ibrahim, A.R., Gavindaraju, V.G.R.C., Supply chain management practices in electronics industry in Malaysia: Consequences for supply chain performance., In: Benchmarking: An International Journal, 2011, 18, 6, 834-855

[20] Hwang, B.N., Lu, T., Key success factor analysis for e-SCM project implementation and a case study in semiconductor manufacturers, In: International Journal of Physical Distribution and Logistics Managements, 2013, 43, 8, 657-687

[21] Talavera, M.G.V., Supply chain management practices and challenges: Case studies of four supply chains, In: Philippine Management Review, 2015, 22

[22] Kumar, A., Ozdamar, L., Zhang, C.N., Supply chain redesign in the healthcare industry of Singapore, In: Supply Chain Management: An International Journal, 2008, 13, 2, 95-103

[23] Mustaffa, N. H., Potter, A., Healthcare supply chain management in Malaysia: A case study, In: Supply Chain Management: An International Journal, 2009, 14, 3, 234-243

[24] Agwunobi, J., London, P.A., Removing costs from the health care supply chain: lessons from mass retail, In: Health affairs, 2009, 28, 5, 1336-1342

[25] Ponomarov, S.Y., Holcomb, M.C., Understanding the concept of supply chain resilience, In: International Journal of Logistics Management, 2009, 20, 1, 124-139

[26] Bigelow, R., Chan, P.S., Managing in difficult times: Lessons from the most recent recession, In: Management Decision, 1992, 30, 8

[27] Dierickx, I., Cool, K., Asset stock accumulation and sustainability of competitive advantage, In: Management Science, 1989, 35, 12, 1504-1511

[28] Tan, K.C., Kannan, V.R., Buyer-supplier relationships: the impact of supplier selection and buyer-supplier engagement on relationship and firm performance, In: International Journal of Physical Distribution and Logistics Management, 2006, 36,10, 755-775

[29] Hoyos, C., The new Seven Sisters: oil and gas giants dwarf western rivals, In: Financial Times, 2007

[30] Vardi, N., The New Seven Sisters: Today's Most Powerful Energy Companies, In: Seeking Alpha, 2007

[31] Lamming, R., Japanese supply chain relationships in recession, In: Long Range Planning, 2000, 33, 6, 757-778

[32] Future of Consumption in Fast-Growth Consumer Markets: INDIA, World Economic Forum, 2019

[33] Thanh, V.T., Duong, N.A., Vietnam after two years of WTO accession: What lessons can be learnt?, In: ASEAN Economic Bulletin, 2009, 26, 1, 115-135

[34] Pincus, J, Vietnam: Sustaining growth in difficult times, In: ASEAN Economic Bulletin, 2009, 26, 1, 11-24

[35] Beresford, M., The Cambodian clothing industry in the post-MFA environment: A review of developments, In: Journal of the Asia Pacific Economy, 2009, 14, 4, 366-388

[36] Natsuda, K., Goto, K., Thoburn, J., Challenges to the cambodian garment industry in the global garment value chain, In: The European Journal of Development Research, 2010, 22, 4, 469-493, http://dx.doi.org/10.1057/ ejdr.2010.21

[37] Miller, D., Business as usual? Governing the supply chain in clothing - post MFA phase-out: The case of Cambodia, In: International Journal of Labour Research, 2009, 1, 1, 9-33

[38] Kai, H., Knut, A., (McKinsey and Company), 5 Lessons for Supply Chains from the Financial Crisis, Available at: https://www.supplychain247.com/article/5_lessons_for_supply_chains_from_the_financial_crisis/one_network_ent erprises [Accessed October 2019]

[39] Holland, T., Katzin, J., (Brain and Company), Beyond the Economic Downturn: Recession Strategies to Take the Lead Now!, Available at: https://www.supplychain247.com/article/beyond_the_economic_downturn_recession_ strategies_to_take_the_lead [Accessed October 2019]

[40] Christopher, M., Peck, H., Towill, D., A taxonomy for selecting global supply chain strategies, 2006, 277-287, http://dx.doi.org/10.1108/09574090610689998

[41] Latham, S., Braun, M., Economic recessions, strategy, and performance: A synthesis, In: Journal of Strategy and Management, 2011, 4, 2, 96-115, http://dx.doi.org/10.1108/17554251111128592

[42] John, W.H., Beverly, D.S., Sypher, H.E., Do shared goals really make a difference?: Methods organization and participants procedures results methods of communication goals and goal sharedness shared goals and organizational commitment shared goals, job satisfaction, and communication ION satisfactory post HOC analysis discussion note references, In: Management Communication Quarterly: McQ (1986-1998), 1992, 6, 2, 166

[43] Cooper, M.C., Ellram, L.M., Characteristics of supply chain management and the implication for purchasing and logistics strategy, In: The International Journal of Logistics Management, 1993, 4, 2, 13-24

[44] Hall, M.A., Correlation-based feature selection for machine learning, 1999

[45] Ritchie, B., Brindley, C., An emergent framework for supply chain risk management and performance measurement, In: Journal of the Operational Research Society, 2007, 58, 11, 1398-1411 
[46] Bogucki Duncan, N., Capturing Flexibility of Information Technology Infrastructure: A Study of Resource Characteristics and their Measure, In: Journal of Management Information Systems, 1995, 12, 2, 37-57

[47] Sambamurthy, V., Bharadwaj, A., \& Grover, V. (2003). Shaping agility through digital options: Reconceptualizing the role of information technology in contemporary firms. MIS quarterly, 237-263.

[48] Gimenez, C., Taco van, d.V., van Donk, D.P. Supply chain integration and performance: The moderating effect of supply complexity, In: International Journal of Operations and Production Management, 2012, 32, 5, 583-610, http://dx.doi.org/10.1108/01443571211226506

[49] Aaker, D.A., Mascarenhas, B., The need for strategic flexibility, In: The Journal of Business Strategy, 1984, 5, 2, 74

[50] Rowe, W.G., Wright, P.M., Related and unrelated diversification and their effect on human resource management controls, In: Strategic management journal, 1997, 18, 4, 329-338

[51] Olson, E.G, Supply chain opportunity in an uncertain economic recovery, In: Supply Chain Management, 2010, 15, 6, 488-492, http://dx.doi.org/10.1108/13598541011080464

[52] Knemeyer, A.M., Zinn, W., Eroglu, C., Proactive planning for catastrophic events in supply chains, In: Journal of operations management, 2009, 27, 2, 141-153

[53] Grötsch, V.M., Blome, C., Schleper, M.C., Antecedents of proactive supply chain risk management - a contingency theory perspective, In: International Journal of Production Research, 2013, 51, 10, 2842-2867

[54] Chowdhury, M.M.H., Quaddus, M., Supply chain readiness, response and recovery for resilience, In: Supply Chain Management: An International Journal, 2016

[55] Richey, R.G., Kovács, G., Spens, K., Identifying challenges in humanitarian logistics, In: International Journal of Physical Distribution \& Logistics Management, 2009

[56] Richey, R.G., Natarajarathinam, M., Capar, I., Narayanan, A., Managing supply chains in times of crisis: a review of literature and insights, In: International Journal of Physical Distribution \& Logistics Management, 2009

[57] Agboola, A.A., Salawu, R.O., Managing deviant behavior and resistance to change, In: International Journal of Business and Management, 2011, 6, 1, 235

[58] Sanders, N.R., IT alignment in supply chain relationships: A study of supplier benefits, In: Journal of Supply Chain Management, 2005, 41, 2, 4-13

Authors:

\section{GURUMURTHY SUGANYA ${ }^{1}$, SELVAKUMAR JOSHUA²}

${ }^{1}$ Anna University, Research Scholar, Management, Sardar Patel Road, Kotturpuram, Chennai, 600025, Tamil Nadu, India

${ }^{2}$ PSG Institute of Management, Associate Professor, Management, 1668, Avinashi Rd, Masakalipalayam, Peelamedu, Coimbatore, 641004, Tamil Nadu, India e-mail: joshua@psgim.ac.in

\section{Corresponding author:}

GURUMURTHY SUGANYA

e-mail: suganya@psgim.ac.in 